Available online/abstracted at http://www.biolineinternational.org.br/njps; www.ajol.info/journals.njps; www.cas.org

\title{
EFFECT OF PETROLEUM PRODUCTS INHALATION ON SOME HAEMATOLOGICAL INDICES OF FUEL ATTENDANTS IN CALABAR METROPOLIS, NIGERIA
}

\author{
A. M. OKORO, E. J. ANI, J. O. IBU, and B. A. AKPOGOMEH \\ Department of Physiology, College of Medical Sciences, University of Calabar, \\ P.M.B.1115, Calabar, Cross River State, Nigeria.
}

\begin{abstract}
Summary: Haematotoxic implications of exposure to petroleum fumes through inhalation in human subjects were investigated. A total of 400 subjects (200 males and 200 females) aged between 18-30 years participated. Each gender was further categorized into two groups of 100 each for control and test, respectively. The test group was again subdivided into test 1 (T1) and test 2 (T2) in both sexes. T1 subjects were exposed to petroleum fumes for two years and below while T2 subjects were exposed for more than two years. Samples of blood were collected daily and subjected to haematological analysis. The results obtained showed that in males and females, red blood cell counts $\left(10^{6} / \mathrm{mm}^{3}\right)$ was significantly $(\mathrm{P}<0.001)$ decreased in $\mathrm{T} 1(4.4 \pm 0.13)$ and $\mathrm{T} 2(3.85 \pm 0.07)$ compared to control $(4.76 \pm$ $0.01)$. There was a significant decrease $(\mathrm{P}<0.01)$ in white blood cell counts, haematocrit, haemoglobin concentration, mean corpusclular haemoglobin concentration (MCHC) in both sexes of test groups when compared with control. There was also a significant $(\mathrm{P}<0.001)$ decrease in mean corpuscular haemoglobin $(\mathrm{MCH})$ and mean corpuscular volume (MCV) in test 2 males compared with control. Most subjects exposed for longer than two years $(\mathrm{T} 2)$ had significantly $(\mathrm{P}<0.001)$ lower values of red blood cell count, haemoglobin concentration and haematocrit than those exposed for less than two years. The odds/odds ratio that a subject would become anaemic progressively rose from less than 1 in the control to greater than 1 or infinity on exposure to petroleum fumes. These results indicate that the petroleum fumes cause a reduction in haematological indices which worsens with prolonged exposure.
\end{abstract}

Key Words: Petroleum products,Haematological indices, Fuel attendants

\section{Introduction}

Fractional distillation of crude petroleum yields different fractions of petroleum of which petrol, kerosene and diesel are constituent parts. These fractions of crude oil contain aliphatic, aromatic and a variety of branded saturated and unsaturated hydrocarbons (Henderson et al, 1993; Kato et al, 1993; Anderson et al, 1995). Occupational exposure to petroleum fumes have been reported to have toxic effects on various organs and systems, and these include respiratory, immune and nervous systems. Organs such as the heart, lungs, skin and kidneys are affected by these toxic effects resulting in various diseases and different forms of genotoxic, mutagenic, immunotoxic, carcinogenic and neurotoxic manifestations(Becker, 1985; Klassen 1990; d'Azevedo et al, 1996; Smith et al, 1996; Rabble and Wong, 1996; Ross 1996; Rothman et al, 1996).

Petroleum products are used for various reasons by human beings at homes, in manufacturing and petrochemical industries. The uses range from fuels for vehicles, cooking and lighting fuels in homes and outside homes, as chemical feedstock for industries as well as for therapeutic reasons (Hockabey et al, 1995). The daily use of petroleum products both in and outside petroleum industries may have effects on users, and those who work directly in petroleum industries (those occupationally exposed) are likely to be more affected than their counterparts who do not work in these industries (Smith et al, 1993; Carbello et al, 1994; Rothman et al, 1996).

Previous research studies carried out were on composite fumes evaporating from kerosene, petrol and diesel and such studies were carried out on experimental animals. Hydrocarbons like benzene, metals like lead and volatile nitrates have all been shown to produce harmful effects on the bone marrow, spleen, and lymph nodes (Marieb, 1995), Most often they add up to other environmental and physiological factors already known, to affect 
blood parameters and the resultant effect is stress in the animals exposed. These toxic compounds destroy or inhibit the haematopoietic component in the red marrow (Marieb, 1995). Benzene, which is an aromatic hydrocarbon contained in gasoline, is known to induce leukaemia during occupational exposure (Austin et al, 1988)

The main objective of this study therefore was to investigate the effect of inhalation of petroleum products on some haematological parameters in humans occupationally exposed namely, Packed cell Volume (PCV), Red blood cell (RBC), Haemoglobin (Hb), Mean Corpuscular Haemoglobin (MCH), Mean corpuscular Volume (MCV), Mean Corpuscular Haemoglobin Concentration (MCHC) and White blood cells (WBC).

\section{Materials and Methods}

Subjects: This study was carried out on adult human subjects aged between 18 to 30 years who gave informed consent to the study. Questionnaires were distributed and accurately filled; candidates who met the criteria for participation in this study were admitted into the study. Several fuel stations located in Calabar metropolis were used as sites for this study (test subjects) while shop attendants and students took part as controls. A total of four hundred subjects took part in this study, consisting of two test groups and two control groups of both sexes - two hundred males and two hundred females. The two hundred males were divided into two groups of one hundred each for test and control. A similar division was done for the two hundred females. The test group was further subdivided into test 1 group (people who had worked for 2 years or less) and test 2 group (people who had worked for more than 2 years).

Venous blood $(5 \mathrm{ml})$ was taken from a peripheral vein on the arm of each subject and immediately transferred into sterile potassium EDTA anticoagulant bottles. The blood samples obtained were analysed on daily basis. The $\mathrm{Hb}$ estimation was done by the spectrophotometric method using Drabkin's solution while packed cell volume was determined by the use of micro-haematocit method. The total red blood cell and white blood cell were counted using the improved Neubauer counting chamber under an Olympus binocular electric microscope i.e. estimation by haemocytometric method.

Statistical analysis

This was carried out by employing student's t-test to compare the mean values of the test groups with the control. A $\mathrm{P}<0.05$ was considered to be statistically significant. Furthermore, the odds and odds ratios for the various RBC indices were calculated to determine the likelihood of subjects becoming anaemic in both control and test groups. Values of odds and odds ratios which were below one were considered unlikely to become anaemic while values above one were more likely to be anaemic, after the method of Bandolier (2006).

\section{Results}

The results obtained as shown in Table 1 compares the mean $\mathrm{Hb}, \mathrm{PCV}, \mathrm{RBC}$, WBC, $\mathrm{MCH}, \mathrm{MCV}$ and $\mathrm{MCHC}$ of the control group with the means of test 1 group and test 2 group for males. Table 2 compares the control group with the test group for females. The $\mathrm{Hb}, \mathrm{PCV}$, $\mathrm{RBC}, \mathrm{WBC}, \mathrm{MCH}, \mathrm{MCV}$ and $\mathrm{MCHC}$ for the control male group were $14.69 \pm 0.01(\mathrm{~g} / \mathrm{dl})$; $46.63 \pm 0.31(\%) 4.76 \pm 0.01\left(10^{6} / \mathrm{mm}^{3}\right), 5.45$ $\pm 0.013\left(10^{3} / \mathrm{mm}^{3}\right), 31.27 \pm 0.04(\mathrm{Pg}), 99.17 \pm$ 0.12 (fl) and $31.53 \pm 0.01(\%)$ respectively.

The values for Test 1 male group for $\mathrm{Hb}, \mathrm{PCV}$, $\mathrm{RBC}, \mathrm{WBC}, \mathrm{MCH}, \mathrm{MCV}$ and $\mathrm{MCHC}$ were $12.36 \pm 0.06(\mathrm{~g} / \mathrm{dl}) ; 38.84 \pm 0.21(\%), 4.07 \pm$ $0.06\left(10^{6} / \mathrm{mm}^{3}\right), 4.40 \pm 0.13\left(10^{3} / \mathrm{mm}^{3}\right)$, $30.75 \pm 0.51(\mathrm{Pg}), 96.55 \pm 1.56(\mathrm{fl})$ and 31.81 $\pm 0.08(\%)$ respectively while the values for Test 2 male group were $11.12 \pm 0.18$ (gldl); $34.98 \pm 0.57,3.85 \pm 0.07,4.49 \pm 0.18,28.95 \pm$ $0.26,91.04 \pm 0.80$ and $31.8 \pm 0.03$ respectively. These results show significant differences $(\mathrm{P}<0.001)$ between the control group and test groups 1 and 2 for $\mathrm{HB}, \mathrm{PCV}, \mathrm{RBC}$ and $\mathrm{WBC}$ while $\mathrm{MCHC}$ was significant at $\mathrm{p}<0.05$. However, $\mathrm{MCH}$ and $\mathrm{MCV}$ only decreased significantly in test 2 when compared with control, while test 1 was not significant.

The Hb, PCV, RBC, WBC, $\mathrm{MCH}$, $\mathrm{MCV}$ and $\mathrm{MCHC}$ for the control female group were $13.66 \pm 0.01,42.81 \pm 0.05,4.61 \pm 0.01$, $4.54 \pm 0.01,29.74 \pm 0.03,93.21 \pm 0.09,31.94$ \pm 0.01 respectively. The values of test 1 female group for $\mathrm{Hb}, \mathrm{PCV}, \mathrm{RBC}, \mathrm{WBC}, \mathrm{MCH}$, $\mathrm{MCV}$ and MCHC were $10.69 \pm 0.06,32.88 \pm$ $0.21,3.65 \pm 0.05,3.33 \pm 0.66,29.63 \pm 0.49$, $91.16 \pm 1.56$ and $32.53 \pm 0.13$ while the values for test 2 female group was $9.45 \pm 0.12,29.18$ $\pm 0.35,3.27 \pm 0.05,3.25 \pm 0.075,29.18 \pm$ $0.49,90.21 \pm 1.59$ and $32.39 \pm 0.1 \overline{6}$ respectively. There were also significant differences $(\mathrm{P}<0.001)$ between the control group and both test groups for $\mathrm{HB}, \mathrm{PCV}, \mathrm{RBC}$, WBC and MCHC (Table 2) while MCH and MCV decreased insignificantly. The results show that the values of all these parameters decreased in the test groups for the females ,with the values for test 2 female group being generally less than test 1 female group. 
Comparing test 1 with test 2 groups in the males showed statistically significant decreases in test $2(p<0.001)$ for RBC,HB and $\mathrm{PCV}$ while $\mathrm{MCH}$ and $\mathrm{MCV}$ were significant at $\mathrm{p}<0.01$. In females, RBC, $\mathrm{HB}$ and $\mathrm{PCV}$ were also significantly decreased in test 2 compared to test 1 while $\mathrm{WBC}, \mathrm{MCH}, \mathrm{MCV}$ and $\mathrm{MCHC}$ were not significant.

Table 1: Haemotological indices in Male fuel attendants exposed through inhalation to petroleum fumes

\begin{tabular}{lccc}
\hline $\begin{array}{c}\text { Haematological } \\
\text { Indices }\end{array}$ & $\begin{array}{c}\text { Non Petrol } \\
\text { attendants } \\
(\text { Control })\end{array}$ & $\begin{array}{c}\text { Petrol attendants } \\
\text { exposed to fumes } \\
<2 \mathrm{yrs}\left(\mathrm{T}_{1}\right)\end{array}$ & $\begin{array}{c}\text { Petrol attendants } \\
\text { exposed to fumes } \\
>2 \mathrm{yrs}\left(\mathrm{T}_{2}\right)\end{array}$ \\
\hline $\mathrm{Hb}(\mathrm{gldL})$ & $14.69 \pm 0.01$ & $12.356 \pm 0.06^{* * *}$ & $11.12 \pm 0.18^{* * *}$ \\
$\mathrm{PCV}(\%)$ & $46.63 \pm 0.31$ & $38.84 \pm 0.21^{* * *}$ & $34.98 \pm 0.57^{* * *}$ \\
$\mathrm{RBC}\left(\mathrm{x} 10^{6} / \mathrm{mm}^{3}\right)$ & $4.76 \pm 0.01$ & $4.07 \pm 0.06^{* * *}$ & $3.85 \pm 0.07^{* * * *}$ \\
$\mathrm{WBC}\left(\mathrm{x} 10^{3} / \mathrm{mm}^{3}\right)$ & $5.45 \pm 0.013$ & $4.40 \pm 0.13^{* * *}$ & $4.49 \pm 0.18^{* * *}$ \\
$\mathrm{MCH}$ & $31.27 \pm 0.04$ & $30.73 \pm 0.51^{\mathrm{NS}}$ & $28.95 \pm 0.26^{* * * *}$ \\
$\mathrm{MCV}$ & $99.17 \pm 0.12$ & $96.55 \pm 1.56^{\mathrm{NS}}$ & $91.04 \pm 0.80^{* * *}$ \\
$\mathrm{MCHC}$ & $31.53 \pm 0.01$ & $31.81 \pm 0.08^{*}$ & $31.8 \pm 0.03^{*}$ \\
\hline
\end{tabular}

$* P<0.05$ compared with control, $* * P<0.01$ compared with control, $* * * P<0.001$ compared with control, ${ }^{\text {NS }}$ - Not Significant with control, Result are presented as Means \pm S.D

Table 2: Haemotological indices in Female fuel attendants exposed through inhalation to petroleum fumes

\begin{tabular}{lccc}
\hline $\begin{array}{c}\text { Haematological } \\
\text { Indices }\end{array}$ & $\begin{array}{c}\text { Non Petrol } \\
\text { attendants } \\
\text { (Control) }\end{array}$ & $\begin{array}{c}\text { Petrol attendants } \\
\text { exposed to fumes } \\
<2 \text { years }\left(\mathrm{T}_{1}\right)\end{array}$ & $\begin{array}{c}\text { Petrol attendants } \\
\text { exposed to fumes } \\
>2 \text { years }\left(\mathrm{T}_{2}\right)\end{array}$ \\
\hline $\mathrm{Hb}(\mathrm{gldL})$ & $13.66 \pm 0.01$ & $10.69 \pm 0.06^{* * *}$ & $9.45 \pm 0.12^{* * *}$ \\
$\mathrm{PCV}(\%)$ & $42.81 \pm 0.05$ & $32.88+0.21^{* * *}$ & $29.18 \pm 0.35^{* * *}$ \\
$\mathrm{RBC}\left(10^{6} / \mathrm{mm}^{3}\right)$ & $4.61 \pm 0.01$ & $3.65 \pm 0.05 * * *$ & $3.27 \pm 0.05^{* * *}$ \\
$\mathrm{WBC}\left(10^{3} \mathrm{~mm}^{3}\right)$ & $4.54 \pm 0.012$ & $3.33 \pm 0.66^{* * *}$ & $3.25 \pm 0.075^{* * *}$ \\
$\mathrm{MCH}(\mathrm{Pg})$ & $29.74 \pm 0.03$ & $29.63 \pm 0.49^{\mathrm{NS}}$ & $29.18 \pm 0.49^{\mathrm{NS}}$ \\
$\mathrm{MCV}(\mathrm{fl})$ & $93.21 \pm 0.09$ & $91.16 \pm 1.56^{\mathrm{NS}}$ & $90.21 \pm 1.59^{\mathrm{NS}}$ \\
$\mathrm{MCHC}(\%)$ & $31.94 \pm 0.01$ & $32.53 \pm 0.13^{* * *}$ & $32.39 \pm 0.16^{* *}$
\end{tabular}

* $P<0.05$ compared with control, $* * P<0.01$ compared with control, $* * * P<0.001$ compared with control, ${ }^{N S}$ - Not Significant with control, Result are presented as Means \pm S.D

Table 3a: Odds/odds ratio for anaemia in male subjects

\begin{tabular}{cccccc}
$R B C$ & $\mathrm{n}$ & Anaemic & $\begin{array}{c}\text { Non- } \\
\text { anaemic }\end{array}$ & $\begin{array}{c}\text { Odds } \\
\text { (Anaemic/Non- } \\
\text { anaemic) }\end{array}$ & $\begin{array}{c}\text { Odds } \\
\text { ratio }\end{array}$ \\
\hline Control & 100 & 37 & 63 & $0.59(59 \%)$ & - \\
Test 1 & 50 & 38 & 12 & $3.17(316.67 \%)$ & 5.37 \\
Test 2 & 50 & 48 & 2 & $24(2400 \%)$ & 40.68 \\
$H b$ & & & & & \\
Control & 100 & 0 & 100 & $0.19(19 \%)$ & 0.19 \\
Test 1 & 50 & 8 & 42 & $2.13(213 \%)$ & 2.13 \\
Test 2 & 50 & 34 & 16 & $0(0.0 \%)$ & \\
$P C V$ & & & 100 & $0.19(19 \%)$ & 0.19 \\
Control & 100 & 0 & 42 & $1.38(138 \%)$ & 1.38 \\
Test 1 & 50 & 8 & 21 & & \\
Test 2 & 50 & 29 & &
\end{tabular}


The normal values for $\mathrm{RBC}, \mathrm{Hb}$ and $\mathrm{PCV}$ used for calculating odds were 5.0-5.5 and 4.5-5.0 $\left(10^{6} / \mathrm{mm}^{3}\right), 14-16$ and $12-14(\mathrm{~g} / \mathrm{dl})$ and $40-50$ and $36-47(\%)$ in males and females respectively. The odds that a male subject would become anaemic, using $\mathrm{RBC}$ as reference, were $0.59,3.17$ and 24.0 for control, $\mathrm{T}_{1}$ and $\mathrm{T}_{2}$ respectively. For $\mathrm{Hb}$ it was $0.0,0.19$ and 2.13 while PCV was $0.0,0.19$ and 1.38 respectively. The odds ratios for $T_{1}$ and $\mathrm{T}_{2}$ were 5.37 and 40.68 for RBC, 0.19 and 2.13 for $\mathrm{Hb}$ and 0.19 and 1.38 for $\mathrm{PCV}$ respectively, as shown in Table 3a. Similarly, the odds of a female subject becoming anaemic, with reference to RBC, were 0.10 , 6.14 and infinite in control, $\mathrm{T}_{1}$ and $\mathrm{T}_{2}$ respectively. For $\mathrm{Hb}$ and $\mathrm{PCV}$, controls were 0.15 and 0.18 respectively while $T_{1}$ and $T_{2}$ were infinite. The odds ratio for $T_{1}$ in the control was 6.14 while $T_{2}$ was infinite with regards to RBC. For $\mathrm{Hb}$ and $\mathrm{PCV}$, the odds ratios for both $T_{1}$ and $T_{2}$ were all infinite (Table 3b).

Table 3b: Odds/odds ratio for anaemia in female subjects

\begin{tabular}{cccccc}
$R B C$ & $\mathrm{n}$ & Anaemic & $\begin{array}{c}\text { Non- } \\
\text { anaemic }\end{array}$ & $\begin{array}{c}\text { Odds } \\
\text { Anaemic/Non- } \\
\text { anaemic) }\end{array}$ & Odds ratio \\
\hline Control & 100 & 9 & 91 & $0.1(10 \%)$ & - \\
Test 1 & 50 & 43 & 7 & $6.14(614 \%)$ & 61.4 \\
Test 2 & 50 & 50 & 0 & Infinite & Infinite \\
$H b$ & & & & & \\
Control & 100 & 13 & 87 & $0.15(15 \%)$ & \\
Test 1 & 50 & 50 & 0 & Infinite & Infinite \\
Test 2 & 50 & 50 & 0 & Infinite & Infinite \\
$P C V$ & & & & & \\
Control & 100 & 15 & 85 & $0.18(18 \%)$ & \\
Test 1 & 50 & 50 & 0 & Infinite & Infinite \\
Test 2 & 50 & 50 & 0 & Infinite & Infinite \\
\hline
\end{tabular}

\section{Discussion}

The haematological parameters $\mathrm{Hb}, \mathrm{PCV}$, $\mathrm{RBC}, \mathrm{WBC}, \mathrm{MCH}, \mathrm{MCV}$ and $\mathrm{MCHC}$ provide information on the general state of the blood of the subjects used for this study. This study has demonstrated that exposure to petroleum fumes causes a significant decrease in RBC values, $\mathrm{Hb}$ values, $\mathrm{PCV}, \mathrm{MCHC}$ and $\mathrm{WBC}$ of subjects exposed to petroleum fumes for any number of years. The toxic components, especially those in petroleum fumes, have been reported to change blood chemistry and induce anaemia by causing bone marrow hypoplasia in experimental animals(Marieb,1995). This study suggests a similar effect on humans. Toxic constituents of crude oil such as Benzene and Lead are reported to be activated in the bone marrow and the cytotoxic effects observed are mediated through disturbance in DNA function. The resultant bone marrow depression is characterized by inadequate production of red cell and other formed elements (Rabble et al, 1996; Synder and Hedli, 1996). This is in line with findings in this study.

White blood cells function primarily in body defense against foreign bodies and this is often achieved through leucocytosis and antibody production (Marieb, 1995; Robbin and Angel, 1976). In this study, the white blood cell count decreased significantly in humans of both sexes exposed to petroleum fumes and the decrease was greater in those exposed for more than two years. Benzene is reported to produce haematological changes ranging from pancytopaenia to total bone marrow aplasia, effected through its myelotoxic action (d'Azevedo et al, 1996). Xylene is also reported to cause leukocytopaenia (d'Azevedo et al, 1995). The decrease in WBC observed in this study is possibly as a result of pancytopaenia and leukocytopaenia, which may result in impaired migration of phagocytic cells, lower resistance to viruses, bacteria and foreign bodies (Marieb, 1995). The observation in this study is similar to previous findings attributed to toxicity from constituents of crude oil, combined with stress imposed by crude oil hydrocarbons (Ovuru and Ekweozor, 2004; Dede and Kagbo, 2002 and Ndodigha et al, 1999).

The odds of a subject becoming anaemic increased progressively from control values to $\mathrm{T}_{1}$ values and were highest in $\mathrm{T}_{2}$. The odds were less than one in the control for $\mathrm{RBC}, \mathrm{Hb}$ and PCV in both sexes, implying that the control subjects were not likely to become anaemic. This is to be expected as they were not exposed to any form of treatment during the experiment. 
However, for the subjects exposed to petroleum fumes for two years and below $\left(\mathrm{T}_{1}\right)$, the odds rose above control values and sometimes to infinity, implying that these subjects were more likely to become anaemic than not. All the subjects exposed to petroleum fumes for more than two years $\left(\mathrm{T}_{2}\right)$ had odds and odds ratios greater than one, implying that they were all likely to become anaemic. Indeed, those that had infinite values were certain to become anaemic and these were mainly among the females, probably due to their normal inherently lower red cell indices. This shows that exposure to petroleum fumes decreases red cell indices in a manner that is duration dependent.

From the results of this study, it is thus concluded that inhalation of petroleum fumes causes depression of total white blood cell count as well as red blood cell count and its dependent haematological indices $(\mathrm{PCV}, \mathrm{Hb})$, $\mathrm{MCH}$ and MCV. Petroleum fumes are therefore environmental pollutants that could have serious consequences on haematological parameters in exposed humans.

\section{References}

Anderson, D., Yu, T. W. and Schmeizer, P. (1995). An investigation of the DNAdamaging ability of benzene and its metabolites in human lymphocytes using the comet Assay. Environ. Mol. Mutat. 26: 305-314.

Austin, H, Delzell E., Cole, P. (1988). Benzene and Leukemia: a review of the literature and risk assessment. Am J. Epidemiol. 127:419.

Bandolier(2006).http://www.jr2.ox.ac.uk/bandolier/ band25/b25-6.html

Becker, C. E. (1985). Principles of occupational Medicine, In; Cecil Textbook of Medicine, $17^{\text {th }}$ ed. (J. B. Wyngaarden and L. H. Smith, Jr. eds.) pp. 2277-2279. W. B. Saunders Co, Philadalphia.

Carbello, M. A., Nigro, M. L, Fraga, I, and Gadano, A. (1994) Ethylene oxide: cytogenic and biochemical studies in persons occupationally exposed. Environ. Mol. Mutagenesis 23 (23): 7.

d'Azevedo, P. A. Tannhauser, A. L. Tannhauser, S. L. (1996). Haematological alternations in rats from xylene and benzene Vet. Human Toxicol 38 (5): 340344.

Dede, E. B., Kagbo, H. D. (2002). A study on the acute toxicological effect of commercial diesel fuel in Nigeria in rats (Ratus ratus) using hematological parameters. J. Appld. Sci. Environ. Management. 6: $84-86$.
Henderson, R. F., Sabourin, P. J., Bechntold, W. E., Steinberg, B. and Chang, I. Y. (1993). Isobutene (2-methylpropene). Toxicol. Appl. Pharmacol, 123: 50 - 61.

Huckabay, P., Wendy D., VanCleave C, Ostrander, J. (1995). Petroleum sector notebook paper. Cameron University. $J$. Appl. Sci. Environ. Mgt, 6: $84-86$.

Kato, M. Rocha, M. L., Carvallio, A.. B., Chaves, M.. E., Rana, M. C. and Oliverra, F. C., (1993). Occupational exposure to neutratoxicants- preliminary survey in five industries of camacari petrochemical complex, Brazil, Environ.. Res. 61: 133139.

Klassen, C. D. (1990). Non metallic environmental toxicant: Air pollutants, solvents, vapour and particles. In: Goodman and Gillman's Textbook, The Pharmacological Basis of Therapeutics $8^{\text {th }}$ ed, A. G. Gilman, T. W. Rall, A. S Niuo and P. Taylor (eds.) NY, Pergamon Press, Pp 1596-1614.

Marieb, E. N. (1995). Human Anatomy and Physiology. $3^{\text {rd }}$ ed. Benjamin and Cummnings Pub Co, California 585-611.

Ndodigha, E. M., Olayimika, F. O., Oruwari, B. M., Ekweozor, I. K. E., Wekhe, S. N. (1999). Toxic effect of crude oil on organs and blood cells of West Africa dwarf goat. Nig. Vet. J. 20:82- 91.

Ovuru, S. S. and Ekweozor, I. K. E. (2004). Haematological changes associated with crude oil ingestion in experimental rabbits. Afr. J. Biotech. 3: 346-348.

Rabble, G. K. and Wong, O. (1996). Leukemia mortality by cell type in petroleum workers with potential exposure to benzene. Environ. Health Perspect 104: 1381 - 1392.

Ross, D. (1996). Metabolic basis of benzene toxicity (Review). Euro. J. Haematol, 60: $111-118$.

Rothman, N., Li, G. L., Dosemeci, M. Bechtold, W. E., Marti G. E, Wang, Y. Z. (1996). Haematotoxicity among Chinese Workers-heavily exposed to benzene from Am, J. ind. Med. 29 (3): 236-246.

Smith, J. H, Mallet, A. K. Brantom, P. G, et al (1996) Ninety days feeding study in Fischer - 344 rats of highly refined petroleum-derived food grade white oils and waves. Toxicol Pathol 24: 214-230.

Smith. T. J., Hammand, S. K., Wond, O. (1993). Health effect of gasoline exposure 1: Exposure assessment for US. Distributions workers. Environ health perspectives 101:13021.

Received: 18/9/06 Accepted: 7/12/06 